\title{
Novel Therapeutic Approach for the Treatment of Alzheimer's Disease by Peripheral Administration of Agents with an Affinity to $\beta$-Amyloid
}

\author{
Yasuji Matsuoka, ${ }^{1,2}$ Mitsuo Saito, ${ }^{1,2}$ John LaFrancois, ${ }^{1}$ Mariko Saito, ${ }^{1,2}$ Kate Gaynor, ${ }^{1}$ Vicki Olm, ${ }^{1}$ Lili Wang, ${ }^{1}$ \\ Evelyn Casey, ${ }^{1}$ Yifan Lu, ${ }^{1}$ Chiharu Shiratori, ${ }^{1}$ Cynthia Lemere, ${ }^{3}$ and Karen Duff ${ }^{1,2}$ \\ ${ }^{1}$ The Center for Dementia Research, Nathan Kline Institute, Orangeburg, New York 10962, ${ }^{2}$ New York University School of Medicine, New York, New York \\ 10016, and 'Brigham and Women's Hospital, Harvard Medical School, Boston, Massachusetts 02115
}

\begin{abstract}
Plaques containing $\beta$-amyloid $(\mathrm{A} \beta)$ peptides are one of the pathological features of Alzheimer's disease, and the reduction of $\mathrm{A} \beta$ is considered a primary therapeutic target. Amyloid clearance by anti-A $\beta$ antibodies has been reported after immunization, and recent data have shown that the antibodies may act as a peripheral sink for $\mathrm{A} \beta$, thus altering the periphery/brain dynamics. Here we show that peripheral treatment with an agent that has high affinity for A $\beta$ (gelsolin or GM1) but that is unrelated to an antibody or immune modulator reduced the level of $\mathrm{A} \beta$ in the brain, most likely because of a peripherally acting effect. We propose that in general, compounds that sequester plasma $\mathrm{A} \beta$ could reduce or prevent brain amyloidosis, which would enable the development of new therapeutic agents that are not limited by the need to penetrate the brain or evoke an immune response.
\end{abstract}

Key words: Alzheimer's disease; amyloid; A $\beta$; peripheral sink; sequestration; binding agent

\section{Introduction}

$\beta$-amyloid $(\mathrm{A} \beta)$ is cleaved from the amyloid precursor protein (APP) by sequential proteolytic processing by $\beta$ - and $\gamma$-secretases, which results principally in the generation of $A \beta 1-40$ and $A \beta 1-42$ (Selkoe, 1993). The accumulation of $A \beta$ is thought to be one of the fundamental pathological events in Alzheimer's disease (AD), and its elevation and/or aggregation has been associated with a range of detrimental cellular responses (Small et al., 2001). One therapeutic approach proposed for the treatment of $\mathrm{AD}$ has been the reduction of CNS A $\beta$ by antibodies raised against $\mathrm{A} \beta$ peptides (Schenk et al., 1999; Janus et al., 2000; Morgan et al., 2000; Weiner et al., 2000; Das et al., 2001) or administered passively (Bard et al., 2000; DeMattos et al., 2001, 2002). One of the proposed mechanisms by which the antibodies may reduce brain $A \beta$ is that anti-A $\beta$ antibodies cross from the periphery to the brain, bind to $A \beta$ in plaques, and stimulate microglial phagocytosis of antibody/A $\beta$ complexes. An alternative proposal based on the observation that anti-A $\beta$ antibodies also significantly influence $\mathrm{A} \beta$ transfer between the brain and plasma (DeMattos et al., 2001, 2002) suggests that periphery/brain A $\beta$ dynamics may play a crucial role in the pathogenesis of $\mathrm{AD}$. Because there are several problems associated with immunotherapy, and current clinical trials of actively administered $\mathrm{A} \beta$ peptides have been suspended after adverse patient response, we have investigated whether com-

Received Sept. 4, 2002; revised 0ct. 21, 2002; accepted 0ct. 23, 2002.

This work was supported by grants from the National Institutes of Health to K.D. and Y.M. and from the Alzheimer Association to Y.M. We thank Dr. Marc Mercken (Johnson \& Johnson Pharmaceutical Research and Development, Beerse, Belgium) for the gift of anti-A $\beta$ antibodies for ELISA.

Correspondence should be addressed to Dr. Karen Duff or Dr. Yasuji Matsuoka, The Center for Dementia Research, Nathan Kline Institute/New York University, 140 Old Orangeburg Road, Orangeburg, NY 10962. E-mail: duff@nki.rfmh.org or matsuoka@nki.rfmh.org.

Copyright $\odot 2002$ Society for Neuroscience $\quad 0270-6474 / 02 / 220029-05 \$ 15.00 / 0$ pounds that are unrelated to antibodies, but which have as their salient feature the ability to bind $\mathrm{A} \beta$ in the periphery, might be effective in altering the periphery/brain dynamics leading to a reduction of brain $A \beta$. For these proof-of-concept experiments, we have chosen two compounds with known $\mathrm{A} \beta$ binding affinity. Gelsolin is a secretory protein known to bind $\mathrm{A} \beta$ via two sites under normal physiological conditions (Chauhan et al., 1999). GM1 is a ganglioside that has a similar affinity for $\mathrm{A} \beta$ (Choo-Smith et al., 1997). We propose that derivative drug structures or nonimmunogenic novel structures that specifically bind pathogenic peptides in the periphery may be clinically efficacious, most likely as prophylactic rather than as therapeutic agents.

\section{Materials and Methods}

Animals. Mice expressing mutant $\mathrm{APP}_{\mathrm{K} 670 \mathrm{~N}, \mathrm{M} 671 \mathrm{~L}}$ (mutant APP, Tg2576) (Hsiao et al., 1996) and mutant presenilin (PS)- $1_{\mathrm{M} 146 \mathrm{~L}}$ (mutant PS-1, line 6.2) (Duff et al., 1996) were crossed to generate PS/APP progeny (Holcomb et al., 1998). Age-matched male and female animals from several litters were equally represented in the vehicle- and drug-treated groups. Two age groups were tested: young mice (at 9-10 weeks of age initially) and mice at 6-7 months of age.

Drug administration and sample preparation. Gelsolin (extracted from bovine plasma; Sigma, St. Louis, MO) or ganglioside GM1 (ammonium salt extracted from bovine brain purchased from Calbiochem, La Jolla, CA) were dissolved in PBS and administered intraperitoneally at a dose of 0.6 and $15 \mathrm{mg} / \mathrm{kg}$ body weight, respectively. Gelsolin was injected every $2 \mathrm{~d}$ for 3 weeks. GM1 was injected every $2 \mathrm{~d}$ for 2 weeks, and the mice were killed after a 1 week washout period. For intracerebroventricular treatment with GM1, an osmotic pump (Alzet, Cupertino, CA) was filled with solution and infused into the lateral ventricle using a brain infusion kit (Alzet) at a dose of $0.15 \mathrm{mg} / \mathrm{kg}$ body weight every $2 \mathrm{~d}$ for 2 weeks.

For plasma assay, tail blood was collected at predrug, mid-drug, 
and postdrug treatment times into preweighed tubes containing 10 mM EDTA in PBS. The volume was adjusted to yield a 1:1 ratio of blood/EDTA-PBS. Plasma was separated by centrifugation at $10,000 \times g$ for 5 min.

Mice were perfused with PBS under anesthesia, and brains were dissected into hemispheres. One of each hemisphere was used for ELISA. Brains were extracted either by four-step extraction according to the method of Kawarabayashi et al. (2001) or by two-step extraction according to Janus et al. (2000).

$A \beta$ quantification. Levels of human $\mathrm{A} \beta 40$ and $\mathrm{A} \beta 42$ in brain extracts and plasma were quantified by ELISA as reported previously (Kawarabayashi et al., 2001) using antibodies supplied by Janssen Pharmaceuticals (Berse, Belgium), as described previously (Refolo et al., 2000). In brief, plates were coated with antibody to either human $\mathrm{A} \beta 40(\mathrm{JRF} / \mathrm{cA} \beta 40 / 10)$ or $\mathrm{A} \beta 42(\mathrm{JRF} / \mathrm{cA} \beta 42 / 26)$. Freshly thawed samples were diluted and incubated overnight. Signal was detected using a horseradish peroxidelabeled antibody, JRF/A $\beta$ tot/17, and an ELISA detection kit (Pierce, Rockford, IL). To confirm that the epitope of ELISA antibodies is not masked, synthetic human A $\beta 40 / \mathrm{A} \beta 42(50 \mathrm{fmol} / \mathrm{ml})$ and GM1 $(20 \mu \mathrm{g} /$ $\mathrm{ml})$ or gelsolin $(9 \mu \mathrm{g} / \mathrm{ml})$ were added in mouse plasma and detected as described above.

Statistical analysis. The hypothesis of no difference among treatments was tested using a one-way multivariate ANOVA followed by Fisher's least significant difference post hoc pairwise comparisons. All tests contrasted one of the treatments with the vehicle (SPSS, Chicago, IL).

Histochemistry. Hemispheres of brains were fixed in $4 \%$ paraformaldehyde overnight and then dehydrated. Two sections at $1.0 \mathrm{~mm}$ lateral from the medial line were stained using biotinylated anti-A $\beta 40 / \mathrm{A} \beta 42$ antibody (clone 6E10; Signet, Dedham, MA) and thioflavin S (Sigma). The area covered by staining in the cerebral cortex and hippocampus was measured using microcomputer imaging device software in a blind manner, and an average of two sections was presented as a percentage of total brain area examined. Statistical significance was determined by $t$ test.

GM1 quantification in plasma and blood cells. Plasma and blood cells were separated by centrifugation. Lipid extracts prepared from $10 \mu \mathrm{l}$ of plasma and $2 \mu \mathrm{l}$ of blood cell suspension in $0.2 \%$ SDS-containing PBS were analyzed on a 96 well plate and on a high-performance thin-layer chromatography plate, respectively, as described by $\mathrm{Wu}$ and Ledeen (1988) with slight modification.

Cholesterol assessment. Total cholesterol was measured in $10 \mu \mathrm{l}$ of plasma from mice at the 2 week time point using a kit (Infinity reagent; Sigma) according to the manufacturer's directions.

\section{Results \\ Peripheral administration of an $\mathrm{A} \beta$ sequestering agent, gelsolin, reduced CNS A $\beta$ in young PS/APP mice}

We tested the effect of peripherally administered gelsolin on brain $A \beta$ load in two groups of PS/APP mice. No overt detrimental systemic effects (change of body weight or enlarged spleen) were seen, and there was no evidence of CNS inflammation (enhanced glial fibrillary acidic protein immunoreactivity) (data not shown). Both groups of mice received drug treatment under the same protocol, but brain $\mathrm{A} \beta$ was extracted by four-step extraction from set 1 mice and by two-step extraction from set 2 mice (Table 1). Four-step extraction yields soluble A $\beta$ in the TBS fraction, membrane-bound $\mathrm{A} \beta$ in the Triton X-100 fraction, and insoluble $\mathrm{A} \beta$ in the SDS and formic acid (FA) fractions. Two-step extraction yields TBS soluble $A \beta$, and all other $A \beta$ is extracted in FA. Gelsolin was injected at an age when pathogenesis is first initiated (9-10 weeks), every $2 \mathrm{~d}$ for 3 weeks, and brain $A \beta$ load was examined (Table 1 ). In both sets of mice, brain $\mathrm{A} \beta$ was significantly reduced by gelsolin treatment ( set $1, p=0.02,0.049$; set $2, p=0.01,0.008$ for $\mathrm{A} \beta 40$ and $\mathrm{A} \beta 42$, respectively). Results for set 1 were lower than for set 2 , because a substantial fraction of $A \beta$ had been extracted into the SDS fraction in the four-step extraction. All of the FA-extracted samples from gelsolin-treated mice were analyzed in duplicate, on the same plate, and the results were
Table 1. Brain $A \beta 40$ and $A \beta 42$ in formic acid extracts from drug-treated and vehicle-treated young PS/APP mice

\begin{tabular}{|c|c|c|c|}
\hline & \multirow[b]{2}{*}{$n$} & $A \beta 40$ & $A \beta 42$ \\
\hline & & \multicolumn{2}{|c|}{ Picomoles of $A \beta$ per gram of tissue } \\
\hline \multicolumn{4}{|c|}{ Gelsolin-treated mice } \\
\hline \multicolumn{4}{|l|}{ Set $1^{a}$} \\
\hline Vehicle & 7 & $199 \pm 29$ & $226 \pm 46$ \\
\hline Gelsolin & 6 & $\begin{array}{c}89 \pm 22 \\
(p=0.02)\end{array}$ & $\begin{array}{c}95 \pm 30 \\
(p=0.049)\end{array}$ \\
\hline \multicolumn{4}{|l|}{$\operatorname{Set} 2^{b}$} \\
\hline Vehicle & 9 & $429 \pm 43$ & $644 \pm 80$ \\
\hline Gelsolin & 7 & $\begin{array}{l}190 \pm 33 \\
(p=0.01)\end{array}$ & $\begin{array}{l}314 \pm 60 \\
(p=0.008)\end{array}$ \\
\hline \multicolumn{4}{|c|}{ GM1-treated mice } \\
\hline Vehicle & 7 & $199 \pm 29$ & $226 \pm 46$ \\
\hline GM1 & 6 & $\begin{array}{l}112 \pm 23 \\
(p=0.03)\end{array}$ & $\begin{array}{l}104 \pm 28 \\
(p=0.04)\end{array}$ \\
\hline
\end{tabular}

Data are presented as mean \pm SEM.

${ }^{a} A \beta$ was extracted by the four-step method (Kawarabayashi et al., 2001).

${ }^{b} \mathrm{~A} \beta$ was extracted by the two-step formic acid extraction method (Janus et al., 2000).

represented as a percentage of vehicle-treated mice (in total, $n=$ 16 for vehicle and $n=13$ for gelsolin; $p=0.003$ and 0.00007 for $\mathrm{A} \beta 40$ and $\mathrm{A} \beta 42$, respectively) (Fig. $1 \mathrm{~A}$ ). Amyloid plaque load ( $n=5$ mice for gelsolin and for vehicle treatment) was assessed by $\mathrm{A} \beta$ immunohistochemistry (to detect both diffuse and compact amyloid) and by thioflavin $S$ staining (to detect fibrillar $A \beta$ ). $\mathrm{A} \beta$ immunoreactive plaque load (percentage of area covered in the cerebral cortex and hippocampus; mean \pm SEM) was significantly reduced by gelsolin treatment (vehicle, $0.170 \pm 0.013$; gelsolin, $0.084 \pm 0.019 ; p=0.011$ ) (Fig. $1 B, C$ ). Thioflavin $\mathrm{S}$-positive plaque load showed a trend toward reduction, but the decline did not reach statistical significance (vehicle, $0.028 \pm$ 0.007 ; gelsolin, $0.013 \pm 0.001 ; p=0.106$ ). This suggests that diffuse $A \beta$ is the likely target of treatment. Plasma $A \beta 40$ and A $\beta 42$ levels in gelsolin-treated mice $(n=6)$ and vehicle-treated mice $(n=7)$ from set 1 were compared before treatment $(0$ weeks), after 1 week, after 2 weeks, or after 3 weeks of treatment. During the initial stage of $A \beta$ deposition, the levels of $A \beta 40$ and $\mathrm{A} \beta 42$ in the plasma of vehicle-treated mice declined (Fig. $1 D$ ); no difference in plasma $\mathrm{A} \beta$ level was detected between vehicle- and gelsolin-treated mice $(p>0.05$ at all time points studied).

Peripheral administration of the $\mathrm{A} \boldsymbol{\beta}$ sequestering agent GM1 also reduced CNS A $\beta$ in young PS/APP mice

We also tested the hypothesis using a second $\mathrm{A} \beta$ sequestering agent, GM1. No overt detrimental systemic effects or evidence of CNS inflammation were seen (data not shown) after 3 weeks of administration. Brain $\mathrm{A} \beta$ extracted by the two-step procedure was significantly reduced by treatment with GM1 ( $p=0.03,0.04$ for $A \beta 40$ and $A \beta 42$, respectively) (Table 1). In the first week of treatment, the level of plasma $\mathrm{A} \beta$ declined in both vehicle-treated animals $(n=6)$ and GM1-treated animals $(n=7)$. In the second week, $A \beta$ levels continued to decline in vehicle-treated mice but did not decline in GM1-treated animals; it was therefore effectively elevated relative to vehicle-treated animals $(p<0.001)$ (Fig. $2 B$ ). Our data have shown that GM1 is cleared rapidly from the plasma (Fig. $2 C$ ) but is maintained in the blood cell fraction for a longer period (Fig. 2D). Plasma GM1 has also been shown to be maintained above the endogenous GM1 level for several days after cessation of administration once steady-state levels have been achieved (Rost et al., 1991). We therefore included a 1 week washout period for the GM1 study. After the washout period (3 


\section{A. Gelsolin, Brain A $\beta$ (ELISA)}

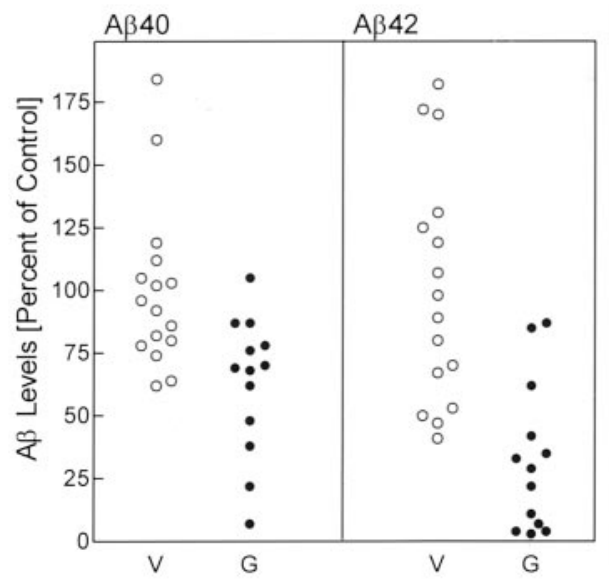

B. A $\beta$ Plaque Load (Vehicle)

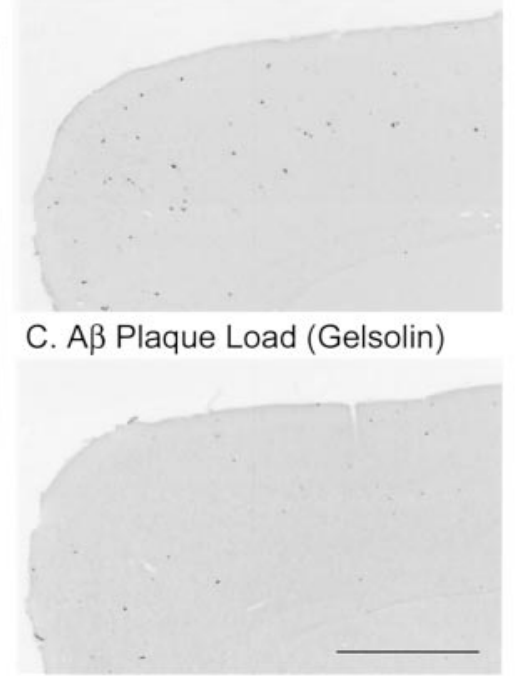

D. Gelsolin, Plasma A $\beta$

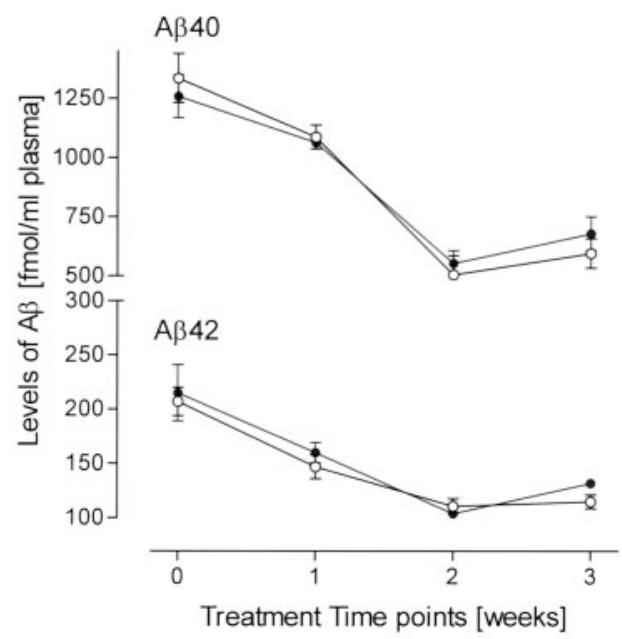

Figure 1. Effect of gelsolin $(\circlearrowleft, G)$ or vehicle $(O, V)$ administration on brain $(A-C)$ and plasma $(D) A \beta$ levels. Brain $A \beta$ load was examined by ELISA $(A)$ and $A \beta$ histochemistry. Typical $A \beta$ immunostaining in mice treated with vehicle $(B)$ and gelsolin $(C)$ is shown. Scale bar, $1 \mathrm{~mm}$. Values represent the mean $\pm S E M$.

\section{A. GM1, Brain A $\beta$}

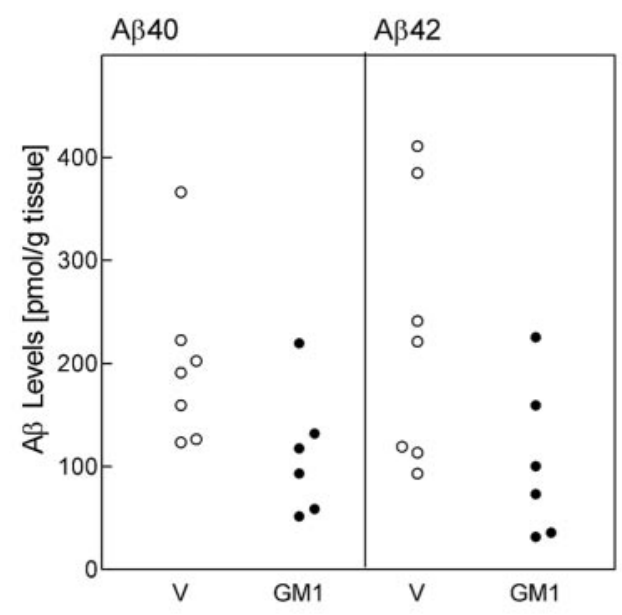

\section{B. GM1, Plasma A $\beta$}

A $\beta 40$

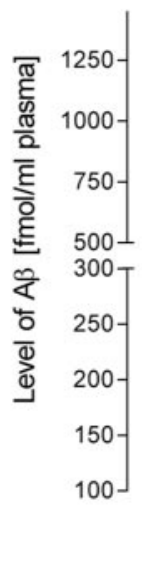

万.

A $\beta 42$
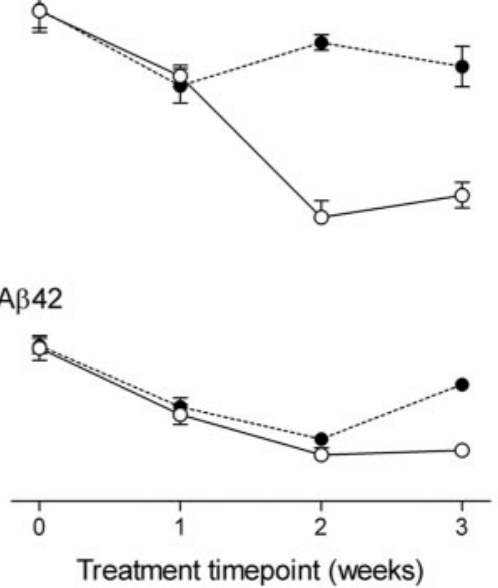

\section{Plasma GM1 Level}

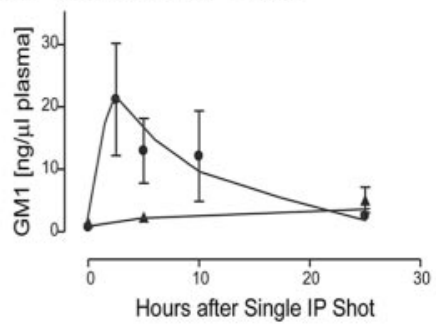

\section{Blood Cells GM1 Level}

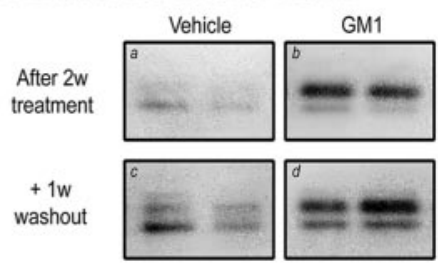

Figure 2. Effect of GM1 $(O)$ or vehicle $(O, V)$ administration on brain $(A)$ and plasma $(B) A \beta$ levels determined by ELISA. The level of GM1 in the plasma $(C)$ was measured after a single administration of drug, over a $24 \mathrm{hr}$ period. GM1 levels were also compared in the blood cell fraction ( $D$ ) of vehicle-treated and GM1-treated mice 2 weeks after treatment initiation and after a 1 week washout period. The upper, augmented band runs concurrent with administered bovine GM1. Values represent the mean \pm SEM.

weeks), the level of $A \beta 40$ was still significantly higher than for vehicle-treated mice ( $p=0.004)$. A $\beta 42$ in GM1-treated mice initially declined similar to vehicle-treated mice, but by the 3 week time point, there was a statistically significant difference between the two groups ( $p=0.001)$. To ensure that the binding of GM1 or gelsolin to $A \beta$ did not reduce the sensitivity of the assay because of epitope masking, ELISA was performed on a known concentration of $\mathrm{A} \beta$ with and without the sequestering agents. The epitope of the detection antibody was not masked to any great degree, because ELISA detected $96-105 \%$ of added human $\mathrm{A} \beta$.

Because GM1 is known to interact with cholesterol (Kakio et al., 2001), and peripheral cholesterol depletion modulates CNS $\mathrm{A} \beta$ levels (Refolo et al., 2001), we measured the level of cholesterol at the 2 week time point in GM1-treated and control mice. Plasma total cholesterol levels were not affected by the dose of GM1 used $(0.46 \pm 0.031$ and $0.45 \pm 0.027 \mathrm{mg}$ of total cholesterol per milliliter of plasma after treatment with vehicle and GM1, respectively). Therefore, the effect of GM1 on CNS A $\beta$ levels is not thought to be caused by a reduction of peripheral cholesterol.

We also investigated the relationship between plasma $\mathrm{A} \beta$ levels and GM1 kinetics, because GM1 is specifically detectable by cholera toxin B subunit. The level of GM1 was measured in the plasma used for $A \beta$ quantification and also in the cell fraction, because the ganglioside is usually membrane-associated. At the 1 and 2 week time points, $2 \mathrm{~d}$ had passed from the last GM1 administration, whereas at the 3 week time point, $8 \mathrm{~d}$ had passed. In the blood cell fraction, GM1 was detected as a doublet band by thinlayer chromatography (Fig. 2D). Faint lower and upper bands of endogenous GM1 were detected in mice receiving vehicle treatment. In mice receiving GM1 for 2 weeks, the upper band was strongly enhanced, and this was maintained after the washout period. The upper band migrated with standard GM1 extracted from bovine brain, suggesting that most of the GM1 in the blood 
Table 2. Brain A $\beta 40$ and $A \beta 42$ in TBS and formic acid extracts after intracerebroventricular infusion of GM1 or vehicle

\begin{tabular}{llll}
\hline & & $A \beta 40$ & $A \beta 42$ \\
\cline { 3 - 4 } & $n$ & Picomoles of $A \beta$ per gram of tissue \\
\hline $\begin{array}{l}\text { TBS-soluble } A \beta \\
\text { Vehicle infusion }\end{array}$ & 7 & $1.1 \pm 0.1$ & $0.7 \pm 0.1$ \\
GM1 infusion & 4 & $5.8 \pm 1.6$ & $2.1 \pm 0.2$ \\
& & $(p=0.04)$ & $(p=0.001)$ \\
FA-soluble $A \beta$ & & $179 \pm 43$ & $210 \pm 37$ \\
$\quad$ Vehicle infusion & 7 & $212 \pm 26$ & $231 \pm 15$ \\
GM1 infusion & 4 & $(p=0.29)$ & $(p=0.98)$ \\
\hline
\end{tabular}

$A \beta$ was extracted by the four-step method (Kawarabayashi et al., 2001). Data are presented as mean \pm SEM.

cell fraction was derived from administered GM1. ELISA measurement of $A \beta$ in the cell fraction from mice at the 2 week time point was uninformative, because the levels were negligible using our preparation protocol. In the plasma fraction, a change in GM1 level was undetectable at any of the time points used for A $\beta$ quantification. However, plasma GM1 was cleared rapidly, because mice treated with a single intraperitoneal injection of the ganglioside showed that GM1 levels in the plasma reached a peak $2.5 \mathrm{hr}$ after the injection and returned to basal levels within $25 \mathrm{hr}$ (Fig. 2C).

The molecular weight of GM1 is 1564 , and $\sim 1 \%$ of peripherally administered GM1 has been shown to cross the blood-brain barrier (BBB) (Saulino and Schengrund, 1994). To assess whether $A \beta$ sequestration in the brain rather than the plasma could account for our results, we infused GM1 directly into the brains of mice for $\sim 3$ weeks and measured $\mathrm{A} \beta$ levels $(n=7$ for vehicle and $n=4$ for GM1 treatment). The amount of GM1 infused into the right lateral ventricle $(0.15 \mathrm{mg} / \mathrm{kg}$ body weight every $2 \mathrm{~d}$ ) was calculated to be approximately equivalent to $1 \%$ of that administered peripherally ( $15 \mathrm{mg} / \mathrm{kg}$ body weight every $2 \mathrm{~d}$ ). $\mathrm{A} \beta$ levels were unchanged in the plasma of mice during or after intracerebroventricular GM1 treatment (data not shown). A $\beta 40$ and $A \beta 42$ levels were significantly increased in the soluble $A \beta$ fraction after 3 weeks of treatment ( $p=0.04,0.001$ for $\mathrm{A} \beta 40$ and A $\beta 42$, respectively). Levels in the Triton X-100, SDS, or FA fractions were unchanged (Table 2). Therefore, administration of GM1 into the brain ventricles directly results in accumulation of $\mathrm{A} \beta$ in the soluble fraction but does not lead to a change in the amount of insoluble/aggregated $\mathrm{A} \beta$.

\section{GM1 administration was not effective in reducing CNS A $\beta$ in mice with severe amyloid burden}

To assess whether GM1 would be effective in reducing A $\beta$ levels in mice with more severe amyloid pathology, we administered GM1 to mice at 6-7 months of age every $2 \mathrm{~d}$ for 2 weeks, followed by the 1 week washout period ( $n=5$ for vehicle or GM1 treatment). Using this protocol, brain and plasma levels of $A \beta$ were unaffected (data not shown). Although it is possible that a longer administration period of GM1 would impact plasma and CNS $\mathrm{A} \beta$ levels to a greater extent, it is also possible that the amyloid load is too great in these mice (or the plaques are too stable) to be impacted by treatment at this stage in disease progression. Interestingly, published vaccine-based therapeutic approaches also failed to reduce CNS A $\beta$ in older mice with significant amyloid load (Morgan et al., 2000; Das et al., 2001), although cognitive impairment was ameliorated (Morgan et al., 2000). Cognitive status in GM1- or gelsolin-treated mice has not yet been assessed.

\section{Discussion}

The recent observations of elevated levels of $A \beta$ in the plasma of another transgenic mouse line (PDAPP) mice after passive immunization with anti-A $\beta$ antibodies (DeMattos et al., 2001, 2002) and in PS/APP mice after active $A \beta$ immunization (Lemere et al., 2002) suggest that alteration of peripheral/brain $A \beta$ dynamics may be a possible therapeutic target, and that this could be achieved simply through peripheral sequestration of $\mathrm{A} \beta$ using compounds that have a high binding affinity for $\mathrm{A} \beta$. We have shown that this is indeed the case, using two systemically administered compounds that bind $\mathrm{A} \beta$ peptides but that do not cross the $\mathrm{BBB}$ to any great degree. Our data support recent findings that the Fab fragment of an anti-A $\beta$ antibody, which lacks immunomodulative effects and acts simply as an $\mathrm{A} \beta$ binding agent, reduced brain $A \beta$ levels significantly (Bacskai et al., 2002).

Young PS/APP mice administered peripherally with gelsolin or GM1 show a substantial decrease in aggregated $A \beta 40$ and $\mathrm{A} \beta 42$ in the brain. Because of its high molecular weight $(86,000$ according to SDS-PAGE), gelsolin is very unlikely to enter the brain when administered peripherally. A small amount of GM1 would be expected to enter the brain, but this is unlikely to be the major cause of reduced CNS A $\beta$, because administration of GM1 into the brain ventricles directly resulted in an increase in soluble $\mathrm{A} \beta$, but insoluble $\mathrm{A} \beta$ levels were unchanged. Although we do not have direct evidence that peripheral sequestration of $A \beta$ is the mechanism underlying the reduction of CNS $A \beta$, our data are supported by previous studies that have strongly suggested that sequestration of $A \beta$ in the periphery by antibodies affects the dynamics of $\mathrm{A} \beta$ efflux and/or influx, which is associated with a concomitant reduction of $\mathrm{A} \beta$ peptides in the brain (DeMattos et al., 2001, 2002; Lemere et al., 2002). Although gelsolin and GM1 administration led to a significant reduction in brain $\mathrm{A} \beta$ levels, plasma $\mathrm{A} \beta$ was affected differently in the two experiments. Vehicle-treated mice undergoing the initial stages of amyloidogenesis show a decline in plasma $\mathrm{A} \beta$, a situation similar to that seen in APP Tg2576 mice in the initial stages of amyloid deposition (Kawarabayashi et al., 2001). The profile for gelsolin-treated animals was very similar to that seen after vehicle treatment, and no change of plasma $A \beta$ was seen between the two groups. $A \beta$ levels in GM1-treated mice were maintained at a higher level relative to vehicle-treated mice, and the profile for $\mathrm{A} \beta 40$ and $\mathrm{A} \beta 42$ was different, with $\mathrm{A} \beta 40$ being affected earlier. It is unknown whether this reflects the initially higher proportion of $\mathrm{A} \beta 40$ relative to $\mathrm{A} \beta 42$ in the plasma, faster clearance of the GM1/ $\mathrm{A} \beta 42$ complex relative to GM1/A $\beta 40$ in the periphery, or slower efflux of $A \beta 42$ from the brain; we also do not know whether the $\mathrm{A} \beta$ species sequestered preferentially is $\mathrm{A} \beta 40$.

The effect of peripheral sequestration with GM1 or gelsolin on plasma $\mathrm{A} \beta$ was minor compared with the elevation in plasma $\mathrm{A} \beta$ seen with passive immunization, but the effects on CNS A $\beta$ levels were similar (Lemere et al., 2002). The lower levels of plasma A $\beta$ in the current study may reflect the lower affinity of gelsolin and GM1 for A $\beta$ (low micromolar range) (Choo-Smith et al., 1997) compared with anti-A $\beta$ antibodies (low picomolar range) (DeMattos et al., 2001), or they may reflect faster clearance of the GM1-A $\beta$ or gelsolin-A $\beta$ complex compared with an IgG-A $\beta$ complex. Lower plasma $A \beta$ levels are unlikely to be an artifact of epitope masking however, because the ELISA recognizes $\mathrm{A} \beta$ in plasma with or without the sequestering agent equally well. At this time, it is difficult to interpret the significance of plasma $\mathrm{A} \beta$ levels relative to brain levels, because the clearance and metabolism of the drugs tested are not clearly defined in this system. 
Additional investigation using a compound with well established pharmacodynamics will be more meaningful.

The relevant contribution of plasma versus CNS $\mathrm{A} \beta$ to the plaques is unclear. Two studies have shown that $\mathrm{A} \beta$ can be cleared to the plasma from the brain (DeMattos et al., 2001, 2002); other studies have shown that radiolabeled peripheral A $\beta$ passes into the brain, where it contributes to the plaque (Ghilardi et al., 1996), and a third study has shown that CNS-derived A $\beta$ can contribute to plaques even in the absence of peripheral $\mathrm{A} \beta$ (Calhoun et al., 1999). At this stage it is unknown whether peripheral sequestration of $A \beta$ prevents the influx or enhances the efflux of $\mathrm{A} \beta$ between the brain and the plasma, but this study shows that the mechanism is effective for a range of different compounds that have as their common feature the ability to bind $A \beta$.

Although our results show GM1 and gelsolin to be at least as effective as immunomodulation-based methods for lowering CNS A $\beta$ levels in the PS/APP mice, the use of these compounds as systemic $A \beta$ sequestering agents is not proposed as a treatment for $\mathrm{AD}$, but rather as a proof-of-concept for a prophylactic approach that may be more flexible, more reliable, and less likely to cause side effects in long-term administration paradigms than immunization-based therapies. There are significant implications for novel drug design not only for AD but also for vascular amyloidosis and other amyloidoses, such as the British, Finnish, and Danish dementias. In addition, it is possible that the peripheral prion protein might be a target, because recent studies have shown that scrapie in transgenic mice can be ameliorated by administration of anti-prion antibodies (Peretz et al., 2001). Given the caveats and limitations associated with antibody-based therapeutics, new drug therapies would be a welcome addition to our pharmacopedic arsenal.

\section{References}

Bacskai BJ, Kajdasz ST, McLellan ME, Games D, Seubert P, Schenk D, Hyman BT (2002) Non-Fc-mediated mechanisms are involved in clearance of amyloid- $\beta$ in vivo by immunotherapy. J Neurosci 22:7873-7878.

Bard F, Cannon C, Barbour R, Burke RL, Games D, Grajeda H, Guido T, Hu K, Huang J, Johnson-Wood K, Khan K, Kholodenko D, Lee M, Lieberburg I, Motter R, Nguyen M, Soriano F, Vasquez N, Weiss K, Welch B, et al (2000) Peripherally administered antibodies against amyloid $\beta$-peptide enter the central nervous system and reduce pathology in a mouse model of Alzheimer disease. Nat Med 6:916-919.

Calhoun ME, Burgermeister P, Phinney AL, Stalder M, Tolnay M, Wiederhold KH, Abramowski D, Sturchler-Pierrat C, Sommer B, Staufenbiel M, Jucker M (1999) Neuronal overexpression of mutant amyloid precursor protein results in prominent deposition of cerebrovascular amyloid. Proc Natl Acad Sci USA 96:14088-14093.

Chauhan VP, Ray I, Chauhan A, Wisniewski HM (1999) Binding of gelsolin, a secretory protein, to amyloid $\beta$-protein. Biochem Biophys Res Commun 258:241-246.

Choo-Smith LP, Garzon-Rodriguez W, Glabe CG, Surewicz WK (1997) Acceleration of amyloid fibril formation by specific binding of $\mathrm{A} \beta-(1-40)$ peptide to anglioside-containing membrane vesicles. J Biol Chem 272:22987-22990.

Das P, Murphy MP, Younkin LH, Younkin SG, Golde TE (2001) Reduced effectiveness of A $\beta 1-42$ immunization in APP transgenic mice with significant amyloid deposition. Neurobiol Aging 22:721-727.

DeMattos RB, Bales KR, Cummins DJ, Dodart JC, Paul SM, Holtzman DM (2001) Peripheral anti-A $\beta$ antibody alters CNS and plasma $A \beta$ clearance and decreases brain $\mathrm{A} \beta$ burden in a mouse model of Alzheimer's disease. Proc Natl Acad Sci USA 98:8850-8855.

DeMattos RB, Bales KR, Cummins DJ, Paul SM, Holtzman DM (2002) Brain to plasma amyloid- $\beta$ efflux: a measure of brain amyloid burden in a mouse model of Alzheimer's disease. Science 295:2264-2267.
Duff K, Eckman C, Zehr C, Yu X, Prada CM, Perez-Tur J, Hutton M, Buee L, Harigaya Y, Yager D, Morgan D, Gordon MN, Holcomb L, Refolo L, Zenk B, Hardy J, Younkin S (1996) Increased amyloid- $\beta 42(43)$ in brains of mice expressing mutant presenilin 1. Nature 383:710-713.

Ghilardi JR, Catton M, Stimson ER, Rogers S, Walker LC, Maggio JE, Mantyh PW (1996) Intra-arterial infusion of $\left[{ }^{125} \mathrm{I}\right] \mathrm{A} \beta$ 1-40 labels amyloid deposits in the aged primate brain in vivo. NeuroReport 7:2607-2611.

Holcomb L, Gordon MN, McGowan E, Yu X, Benkovic S, Jantzen P, Wright K, Saad I, Mueller R, Morgan D, Sanders S, Zehr C, O'Campo K, Hardy J, Prada CM, Eckman C, Younkin S, Hsiao K, Duff K (1998) Accelerated Alzheimer-type phenotype in transgenic mice carrying both mutant amyloid precursor protein and presenilin 1 transgenes. Nat Med 4:97-100.

Hsiao K, Chapman P, Nilsen S, Eckman C, Harigaya Y, Younkin S, Yang F, Cole G (1996) Correlative memory deficits, A $\beta$ elevation, and amyloid plaques in transgenic mice. Science 274:99-102.

Janus C, Pearson J, McLaurin J, Mathews PM, Jiang Y, Schmidt SD, Chishti MA, Horne P, Heslin D, French J, Mount HT, Nixon RA, Mercken M, Bergeron C, Fraser PE, George-Hyslop P, Westaway D (2000) A $\beta$ peptide immunization reduces behavioural impairment and plaques in a model of Alzheimer's disease. Nature 408:979-982.

Kakio A, Nishimoto SI, Yanagisawa K, Kozutsumi Y, Matsuzaki K (2001) Cholesterol-dependent formation of GM1 ganglioside-bound amyloid $\beta$-protein, an endogenous seed for Alzheimer amyloid. J Biol Chem 276:24985-24990.

Kawarabayashi T, Younkin LH, Saido TC, Shoji M, Ashe KH, Younkin SG (2001) Age-dependent changes in brain, CSF, and plasma amyloid $\beta$ protein in the $\operatorname{Tg} 2576$ transgenic mouse model of Alzheimer's disease. J Neurosci 21:372-381.

Lemere CA, Spooner ET, LaFrancois J, Malester B, Mori C, Leverone JF, Clements JT, Selkoe DJ, Duff KE (2002) A $\beta$ immunization of PS/APP mice leads to decreased cerebral $\mathrm{A} \beta$ and a corresponding increase in serum A $\beta$. Soc Neurosci Abstr 27:687.10.

Morgan D, Diamond DM, Gottschall PE, Ugen KE, Dickey C, Hardy J, Duff K, Jantzen P, DiCarlo G, Wilcock D, Connor K, Hatcher J, Hope C, Gordon M, Arendash GW (2000) A $\beta$ peptide vaccination prevents memory loss in an animal model of Alzheimer's disease. Nature 408:982-985.

Peretz D, Williamson RA, Kaneko K, Vergara J, Leclerc E, Schmitt-Ulms G, Mehlhorn IR, Legname G, Wormald MR, Rudd PM, Dwek RA, Burton DR, Prusiner SB (2001) Antibodies inhibit prion propagation and clear cell cultures of prion infectivity. Nature 412:739-743.

Refolo LM, Malester B, LaFrancois J, Bryant-Thomas T, Wang R, Tint GS, Sambamurti K, Duff K, Pappolla MA (2000) Hypercholesterolemia accelerates the Alzheimer's amyloid pathology in a transgenic mouse model. Neurobiol Dis 7:321-331.

Refolo LM, Pappolla MA, LaFrancois J, Malester B, Schmidt SD, ThomasBryant T, Tint GS, Wang R, Mercken M, Petanceska SS, Duff KE (2001) A cholesterol-lowering drug reduces $\beta$-amyloid pathology in a transgenic mouse model of Alzheimer's disease. Neurobiol Dis 8:890-899.

Rost KL, Brockmoller J, Weber W, Roots I (1991) Multiple-dose pharmacokinetics of ganglioside GM1 after intravenous and intramuscular administration to healthy volunteers. Clin Pharmacol Ther 50:141-149.

Saulino MF, Schengrund CL (1994) Differential accumulation of gangliosides by the brains of MPTP-lesioned mice. J Neurosci Res 37:384-391.

Schenk D, Barbour R, Dunn W, Gordon G, Grajeda H, Guido T, Hu K, Huang J, Johnson-Wood K, Khan K, Kholodenko D, Lee M, Liao Z, Lieberburg I, Motter R, Mutter L, Soriano F, Shopp G, Vasquez N, Vandevert C, et al (1999) Immunization with amyloid- $\beta$ attenuates Alzheimer-disease-like pathology in the PDAPP mouse. Nature 400:173-177.

Selkoe DJ (1993) Physiological production of the $\beta$-amyloid protein and the mechanism of Alzheimer's disease. Trend Neurosci 16:403-409.

Small DH, Mok SS, Bornstein JC (2001) Alzheimer's disease and A $\beta$ toxicity: from top to bottom. Nat Rev Neurosci 2:595-598.

Weiner HL, Lemere CA, Maron R, Spooner ET, Grenfell TJ, Mori C, Issazadeh S, Hancock WW, Selkoe DJ (2000) Nasal administration of amyloid- $\beta$ peptide decreases cerebral amyloid burden in a mouse model of Alzheimer's disease. Ann Neurol 48:567-579.

Wu GS, Ledeen R (1988) Quantification of gangliotetraose gangliosides with cholera toxin. Anal Biochem 173:368-375. 